\title{
Tracing the Political-economy Background of the Contemporary Crisis
}

\author{
Noralv Veggeland \\ Dept. of Economics and Organizational Science, Lillehammer University College \\ Postboks 952, 2604 Lillehammer, Norway
}

Tel: 47-61-288-000Ｅ-mail: noralv.veggeland@hil.no

Received: February 10, 2012 Accepted: March 4, 2012 Published: April 1, 2012

doi:10.5296/jmr.v4i2.1375 URL: http://dx.doi.org/10.5296/jmr.v4i2.1375

\begin{abstract}
Economics goes back a long way under shifting political conditions. The Keynesian state's macro-economic form of intervention actions, which developed just after the Second World War, was a clear answer to the structural economic crisis of the inter-war period of the 1920s and 1930s. The Keynesian economic theory was in many senses deduced from classical economic theories. Correspondingly, today we see the Keynesian principles being transformed but prolonged, despite change of framework. The ongoing financial and debt crisis needs an answer of solution, and the answer seems to be found in principles which could be traced and identified as neo-Keynesianism and neo-interventionism. This paper is tracing and analyzing the political economy of the historical democratic capitalism.
\end{abstract}

Keywords: Political economy, Economic theory, Economic crisis, Interventionism, Keynesianism, Transformation 


\section{Neo-Interventionism and Neo-Keynesianism of Today}

There is an ongoing crisis in Europe, characterized by being both a credit and a financial crisis. Measures are needed, therefore causing the EU to become active as an interventionist state in the sense of what John Maynard Keynes recommended (1936). However, principally the framework has change and is new, thereof the introduction of the concepts of neo-interventionism and neo-Keynesianism.

The EU has made important interventionist steps to counteract the crisis, particular deeply experienced in member states like Greek, Italy, Spain, Portugal, Ireland and Hungary, by claiming firmly reduction in public spending, reducing salaries and lowering pensions. On the other hand the EU established a stability fund near 1000 billion euro to help states in trouble. In December 2011 the European Central Bank (ECB) presented an intermediary but long term solution to heal the actual debt problems of certain states; the Long Term Re-financial Operation (LTRO). The aim of the operation is to support the banks with money by an exchange procedure: Banks sell expensive old bonds and gilts, turned over in the market with 6 - 9 per cent interest rate, to the ECB and get fresh money in return. The banks agree on paying the money back in three years times at the same price. For the money the banks need only to pay an interest rate of only 1 percent in return. The measure is meant to secure the bank's liquids. The common understanding is that the banks use their money to buy new state bonds and gilts to secure access to financial assets for those countries. In the first round of exchanging money $€ 500$ billion were taken over from the ECB by the national banks, and the amount has been more than double since then. The problem with this measure which makes it intermediary is that the debt as such has not disappeared. What is needed is real economic growth and creation of jobs.

The supranational EU interventionism in the wake of the ongoing crisis also aims to lower the degree of devolution and national independence. Europe took a major step towards full fiscal union last year, as every EU member country, except the UK and the Czech Republic, vowed to cut budget deficits and submit themselves to greater scrutiny from the European Commission.

The EU member states, 25 out of 27 states, voted for the so called "Financial Pact", which gives the EU and its institutions the authority to control member states ability and political will to keep their national budgets in accordance with EU economic and financial rules and regulations. The agreement is seen as a significant victory for German Chancellor Angela Merkel, who spent months pushing for eurozone members to agree on tighter budgetary constraints. Under the treaty, signatories will agree to cut budget deficits and reduce national debts as a proportion of their economic output or face "automatic" fines, likely to stand at 0.5 per cent of GDP. Sanction will be put in place if the national debt exceeds 3 per cent of the GNP. - National interventionism is losing adequate rendering, and governing democratic authorities are becoming emptied for power.

The political scientist, Wolfgang Streeck writes in Le Monde diplomatique (January 2012) that "Markets dictates what believed sovereign democratic states may and may not do for their citizens. Consequently, the citizens do not respect their elected representatives as their 
own but identify them as representatives for interests of other states and international organizations. Streeck is right but one word should be replaced by another word. It is not the market but supranational regulation which dictates sovereign states. To be dictated is the price to pay for overcoming the contemporary; the regulations generate new forms of supranational interventionism and adequate ideas. The neo-interventionist and neo-Keynesianism thinking is differently executed though, seen in contrast to Keynes' interventionism which was directed to the promotion of economic stability and national effective demand. The latter interventionism was aiming national market regulation by economic demand interventions (Shonfield 1969), rather than debt reduction, contrary, Keynes recommended the raising of public loan in order to realize effective demand objectives.

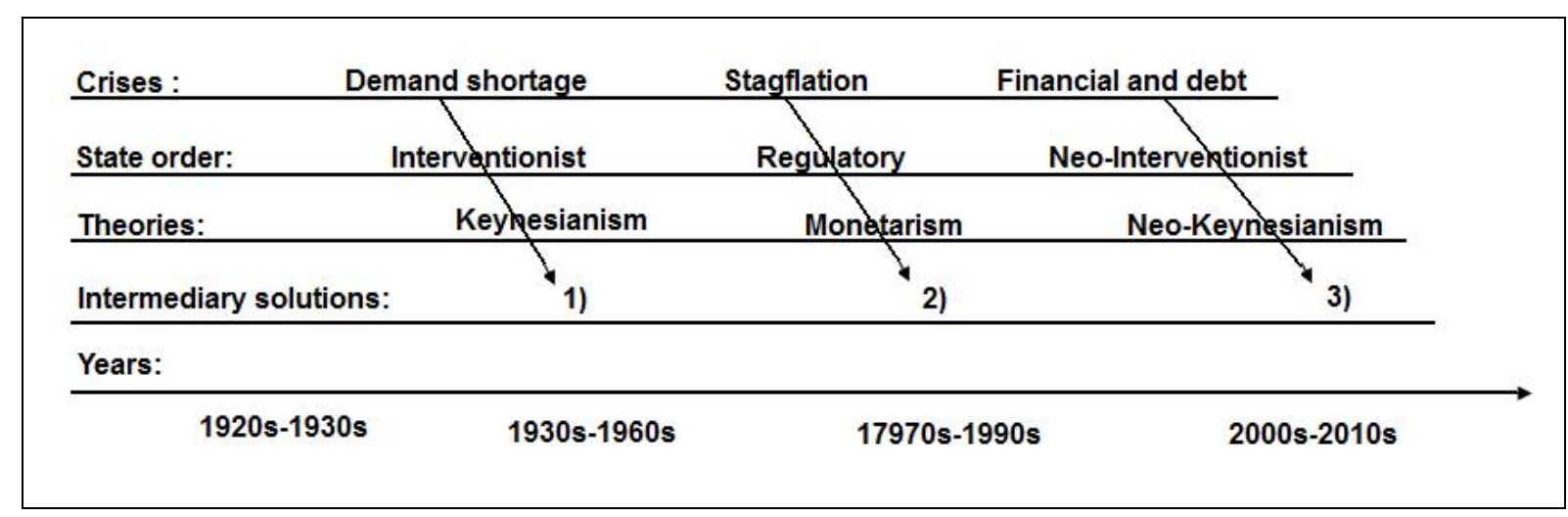

Figure 1. Solutions of international economic crises, 1), 2), 3) promote changes in state orders and choices of predominant economic theories. Different theories get transformed to ideology when not valid as solutions any longer.

Figure 1 sketches the structure of this paper. International economic crises of our time have their history. Before the Second World War, in the 1920s, there occurred a pre-Keynesian demand crisis causing threatening unemployment in Western states. The state reacted passively, and its policy shaped accordingly relying on classical liberal economy theories. In the paper we will review some of those classical economists; Adam Smith, Davis Ricardo and Thomas Robert Malthus - leading up to Karl Marx and Keynes. In the 1930s John Maynard Keynes wrote his “General Theory of Employment, Interest and Money” (1936)”, which introduced the principle of the interventionist state. The theory claimed the necessity of an active state to secure effective demand in order to overcome the ongoing pre-war demand crisis.

The Keynesianism as a political strategy succeeded until the 1970s, when the stagflation crisis undermined the previous enduring economic stability. The intermediary solution to the stagflation crisis was politically to leave Keynesian principles behind, and during the 19 80-1990s to establish a monetary, supply side economy. The theory was deducted from ideas 
promoted by the so called Vienna School of monetary economists which rejected a dominant state function as adequate for the creation of economic growth and stability (Friedman 1980, Veggeland 2009, 2010). The monetary economic policy turned bankruptcy. In the late 2000s the international financial and debt crises occurred and became a grave challenge for Western governments. The contemporary crisis is a double crisis caused by both dysfunctional public and private debt and loans. What is clear is that this double crisis has made the governments and the EU to become active and stick to interventionism in the sense of what John Maynard Keynes recommended (1936). Consequently, we may talk about the occurrence of neo-interventionism as a new state order rooted in neo-Keynesianism theory, see Fig. 1.

\section{Principles of the Pre-Keynesian State}

The interventionist state's macro-economic form of central planning actions, which developed just after the Second World War, was a clear answer to the structural economic crisis of the inter-war period of the 1920s and 1930s, see Figure 1. The legitimacy, which this form of planning gave the state to intervene in the market, is primarily connected with the work of the John Maynard Keynes, the English economist. In 'The General theory of Employment, Interest and Money', from 1935, where parts of the content had already been published elsewhere, Keynes elaborated a new foundation for the understanding of economic growth and its conditions in the market economy. This entailed studies of the causes behind economic fluctuations, and what determine the level of national income and employment. Even though Keynes was a liberal economist he opposed the laissez-faire perspective and marked the clear need for state intervention to tame the market and to escape and avoid economic crises. For these reasons there has been talk of the 'the Keynesian Revolution'. In this context Andrew Shonfield (1969: 3) puts forward an essential question:

What was it that converted capitalism from cataclysmic failure which it appeared to be in the 1930s into the great engine of prosperity of the post war Western World? There is no simple answer, which rests on a denial of the validity of the question itself. The economic order under which we now live and the social structure that goes with it are so different from what preceded them that it is misleading - so it is alleged - to use the word “capitalism” to describe them.

Through his work Shonfield (1969: 3-39) gives answers to the 'conversion' question, which could be summoned up as the following: Keynes' General Theory provided the rationale for state interventions, effective demand, and spending to achieve recovery and full employment. It revolutionized business-cycle theory and established the framework for modern macro-economic analysis including growth economics. In terms of references the effects of this work could aptly be called the 'Keynesian Revolution', Schonfield suggests.

As always happens along lines of ideas, historically they occur before an actual revolution which bias evolution of socio-economic theories and political ideologies. This was also the case regarding the ideas, which shaped the 'Keynesian Revolution'. A number of predecessors contributed as founding fathers of the economic ideas and legitimated the 
intervention of the market which led up to the Keynesianism. The ideas were all colored of the social setting in which they were innovatively design, and inspired by the political ideas and ideological approaches of the time like liberalism, utilitarism, and socialism. Let us look more closely into some of these 'founding fathers'(Stewart 1972, Schumpeter 1939).

Adam Smith: Economics goes back a long way under shifting political conditions. Adam Smith, who published 'The Wealth of Nations' in 1776 one can take as the founder of modern economics. Despite his concern with what we call conditions for 'economic growth', the book contains no real discussion of why the level of employment is what it is and how market should be intervened and regulated. At the time agriculture was still by far the most important activity, and in an agricultural society the notions of being employed and being unemployed were not really distinctive: the whole family works, but might seasonally be underemployed. Smith simply assumed that there was always full employment. Regarding regulation, he in line with the liberal political thinking and classic economic theory of time he believed in the 'invisible hand' as the regulatory and taming principle of the market. He just commented one thing though, that of course 'landlords talk together' and they make their decisions and agreements and intervene on prices when they unavoidably meet now and then. This phenomenon he recognised as a negative externality which might disturb the rule and efficiency of the 'invisible hand', and thereby the balance of the economy. It represented a socio-economic risk that should be avoided. He never put forward the idea that such 'decisions and agreements' were indeed a human way of taming the actual markets.

Adam Smith took over the idea that the economic sphere was a sort of nature and therefore stable and structured by 'natural law'. This view he elaborated upon the contributions of the great founders at the time of political liberalism - especially John Locke (1632-1704). For Locke, a state of nature existed before the occurrence of the social contract conducted by the political state. In that pre-organized state each individual was facing nature and free interaction. They had to deal with work, the products and utility of the work, and property rights, therefore each man was a homo economicus. The social contract and the state control emerged only in reaction to threats and with the obligation to protect the natural law and the private property. Adam Smith took the idea of the 'natural man' as the 'economic man' and made it basic in his theory. He reaffirmed both the liberal view that the economic sphere should remain free and have historical and ideological precedence over other spheres of societal life.

David Ricardo: The next economist of major founder importance is David Ricardo, who published the first edition of his 'Principles of Political Economy and Taxation' in 1817. Like many other nineteenth century economists his main interest lay in the factors, which are steering the distribution of a nation's income between the major social classes - landowners, capitalists, and workers, i.e. rent, profits and wages in corresponding order. The capitalists must make large profits, accumulate money, he said, because they would invest them in new machinery; and this would create more employment and enable more to be produced. Ricardo operated in the optimism of the dawn of the industrial society. Typically, the issue of state interventions was not in the focus of Ricardo that was instead liberation of potentiality and ability. 
Thomas Robert Malthus: Thomas Robert Malthus, another economist at the time, is best known for his theory of population. According to him there is tendency for the population to increase exponentially while the supply of food, only increase linearly. This represented the first socio-economic risk, which Malthus reviewed.

The theory had its background in the actual population explosion in Europe, and the occurrence of extensive emigration waves to America. Hence, with this part of Malthus' work Ricardo did not disagree. But there was another part he opposed. Against Ricardo's theory of profits and investment in production machinery, Malthus argued on two levels. At one level he pointed out that there was a danger that the investment would raise the production capacity at a faster rate than the ability of the society to consume. Of the wages received by the workers only a part of it will be used to buy goods, which are produced because of the investment. Investment increases the production, but the nation state will find itself with a 'general glut of commodities', which cannot be sold. Will this not lead to unemployment, he asked? This was another risk. And on the second level, he went on asking: Actually, there is a large class of landowners and capitalists that certainly not invest their money; they tend to save their money, producing nothing, but consuming a lot, the third risk Malthus recognised. Malthus pointed out calamities but none principles or means to avoid them or at least for taming them by interventions.

Ricardo seems to some extent to have accepted the logic of Malthus' thinking, but his answer was that an economy might suffer from shortage of what he called 'effective demand' time by time but not in the long run. He eliminated the Malthusian third identified risk. Actually, Ricardo was more or less right at the time when he elaborated his theory. During the early nineteenth century the only way most industrialists could finance new buildings and machinery needed to expand their business was out of their own profits. Keynes said later on that 'Ricardo conquered England as completely as the Holy Inquisition conquered Spain' (quotation from Stewart 1972: 27) ${ }^{1}$. His influence occurs important to day in the shadow of the regulatory state regime belief in supply-side economics, in tax cut and low interest rate in order to increase the inclination of economic investments. This of relevance for the OECD Anglo-Saxon member states in particular (Sachs 2006).

Karl Marx: As an economist Karl Marx was clearly in the debt of Smith and Ricardo. Much of his framework he took over and gave it a new view. Marx published his main work, 'Das Kapital, in 1867. He was the first leading economist to notice that by the middle of the nineteenth century heavy unemployment, like today, was quite common in the developing industrial European states, and tried to find the reasons why. He reasoned that competition forces capitalists to invest their profits in labor-saving machinery, for if they do not their efficiency will fall, and they will be forced out of business. Of self-interest they will continue to do so. But when doing it, there will also be a fall in employment and the unemployment

\footnotetext{
${ }^{1}$ In terms of reference and in the framework of contemporary neo-liberal economic theory and policies, it might be stated that the profit - investment logic of Ricardo at the end of the nineteenth century conquered the whole of the Western world.
} 
will rise. For those who still have jobs the alternative is to accept lower wages forced upon them by the capitalists.

According to Marx a fall in employment also meant a fall in profits because only work creates economic values (forgotten in today's focus of financial capital?). The clue in the view of Marx is that when this happened, and contrary to what Ricardo had assumed they would, in the long run have little incentives to invest their profits. And since only a small part of the capitalists' profits can be spent on consumption the general surplus of commodities that Malthus had been afraid of would become a reality. Marx elaborated a theory of crisis: A crisis will occur as a result of that unemployment will get heavier and heavier. The basic reason for that is the relentless fall of the profits, which leads before long to a general economic crisis, like our contemporary international crisis. Marx identified an institutional risk inherited in the capitalist system but saw none intervention principle, he saw only the revolution and the breakdown of the capitalist system as the ultimate solution.

Marx theory, certainly, was on the one hand colored by the strong tension between social classes in the developing industrial society in Europe at the time, between the repressed working class and the exploding class of capitalists. On the other hand it was colored by a strong technological belief, a belief in the liberation power of the promising productivity of the new machinery, and the ways of organize it. These production forces in the hand of the working class embedded the ability to free them from the serfdom of wage-work, and would make them economically and politically free as to sides of the same coin. Nevertheless, in spite of the historical fact that his theory about the relentless fall of the profits, the impossibility of balance the trade cycle, and the economic development in general, had limited validity, Marx did represent a significant figure in the evolution of economic theory, and indirectly in state intervention principles by inspiring Keynes. Michael Stewart writes (1972: 33):

'It was much more difficult, after he (Marx) had written, to believe that the capitalist economy, if left to its self, would necessarily function satisfactorily. In particular, it was more difficult to accept Ricardo's view that profits were always invested in new machinery'.

Certainly, Keynes learned from the Marxian lesson. But do have the contemporary monetary economists of the regulatory state learned from this lesson (Veggeland 2009)? And what about Ricardo's effective demand issue approach denying the risk of limited investment might disturb the economies; was his thinking correct? In other paragraphs we are going to give answers by explore occurrence of disturbances in later trade-circles.

\section{The Political Economy of the Interventionist Keynesian State}

Keynes' great contribution to economics, General Theory of Employment, Interest and Money (1936), was to see how the modern economy did not work in the way classical liberalists had supposed, and to provide a new and completely convincing explanation of how it did work. With the interwar economic crisis as background he demonstrated innovatively that heavy unemployment was not a temporary deviation from the normal state of 
development, but could represent an equilibrium situation, which could go on forever (see Figure 1 of today's situation of unemployment). If full employment was wanted it was no good doing to follow the recommendation proclaimed by classic liberal economic theory the government sitting back and hoping for the best, i.e. laissez-faire policy. It must ensure through interventions that there is enough effective demand in the national economy to create full employment.

Hence 'effective demand' is a key notion in the Keynesian theory. As already pointed out, this notion was essential also in the dispute between Malthus and Ricardo more than hundred years earlier. Malthus suggested that an economy might suffer from disturbance, namely shortage of what he called 'effective demand', while Ricardo more or less denied this assumption. Michael Stewart (1972: 30) indicates that Keynes was perhaps reading too much into Malthus when he said, in his Essay on Malthus:

'One cannot rise from a perusal of this correspondence (between Malthus and Ricardo) without a feeling that the almost total obliteration of Malthus' line of approach and the complete domination of Ricardo's for a period of a hundred years has been a disaster to the progress of economics'.

Nevertheless, reading too much or not into what Malthus had grasped rather intuitively, Keynes founded a 'revolutionary' theory on the disputed notion of effective demand. Contrasting a monetary perspective, in his theory effective demand simply means 'demand backed by money' - in other words actual expenditure. The crucial question then is, what determines effective demand? In order to answer Keynes broke down aggregated effective demand into two components, consumption and investment, and claimed it necessary to study each in turn, but also how they could interact in the economy for the purpose of creating full employment.

According to Keynes:

Consumption: Aggregated consumption in an economy relies on wages and income; the latter represent purchasing power ${ }^{2}$. Purchasing power may give variable expenditures as output depending on the size of the wages. Besides it depends quite a lot on how the National Income is distributed, socially and geographically. Consumption might be more than just private consume, it might also be investment if the consumption is part of running businesses. And further, buying a car might be private consumption, but used by the firm it turns out to be an investment. Increasing consumption of any kind expands the effective demand in the economy.

Investment: Money spent on investment is determined by two things; by the amount the investment will yield, the profit, and by the variable cost of borrowing the money needed to finance the investment. The cost is variable because of changing interest rates ${ }^{3}$, though it seems fairly obvious. No one is going to borrow money in order to finance a factory machine or an accommodation facility if the interest payments exceed the profits eventually made by

\footnotetext{
2 Before consumption wages and income are needed.

${ }^{3}$ For the monetarists the interest rate is a steering instrument.
} 
the factory and the facility ${ }^{4}$. But the other way around, if profits exceed the costs, investment will be decided made, resulting in an expansion of the effective demand at an aggregated level.

What challenged Keynes then as being an economist believing basically in liberal economic principles, was how to stabilize consumption and investment on a level of full employment, a thinking almost forgotten by governments today. Full employment and full utilization of the production forces in general, is essential in the theory, neither less nor more than full utilization. 'More' would mean pressure in the aggregated economy with rising prices and increasing inflation as a negative consequence.

What then could be the proper measure, to balance full employment and stable low inflation rate, as part of his effective demand concept of consumption and investment?

Keynes did not believe in Ricardo's view that profits were always invested in new machinery', nor did he believe in Marx's thesis about the relentless fall of the profits. In his theory he introduced an idea with the greatest political implications: the advantage of state interventions in the market in order to balance employment and inflation, see Fig. 2 below, through using public consumption and investment as regulatory measures, and planning and centralized administration as steering instruments. This is what Majone (1994: 77) calls the 'dirigiste state of the past', which was replaced by the regulatory state.

The interventionist state as an instrument to counteract risk in a market economy is a theoretical as well as a practical concept. But according to Keynes, the interventions should only be temporary, to overcome the international economic crisis of the 1930s, he promised, as the liberal economist he was. It should turn out differently, we now know, it became the theoretical foundation of the adjusted permanent modern interventionist state - actually the post war social democratic welfare state lasting until the 1970s and 1980s, see Figure 1, (Veggeland 2007, Flora et al. (eds.) 1999).

Let us try to illustrate some of the Keynesian principles by formalizing structures.

\footnotetext{
${ }^{4}$ Well, in the ongoing basically loan-driven international crisis foregoing borrowing behaviour deviate from this normal.
} 


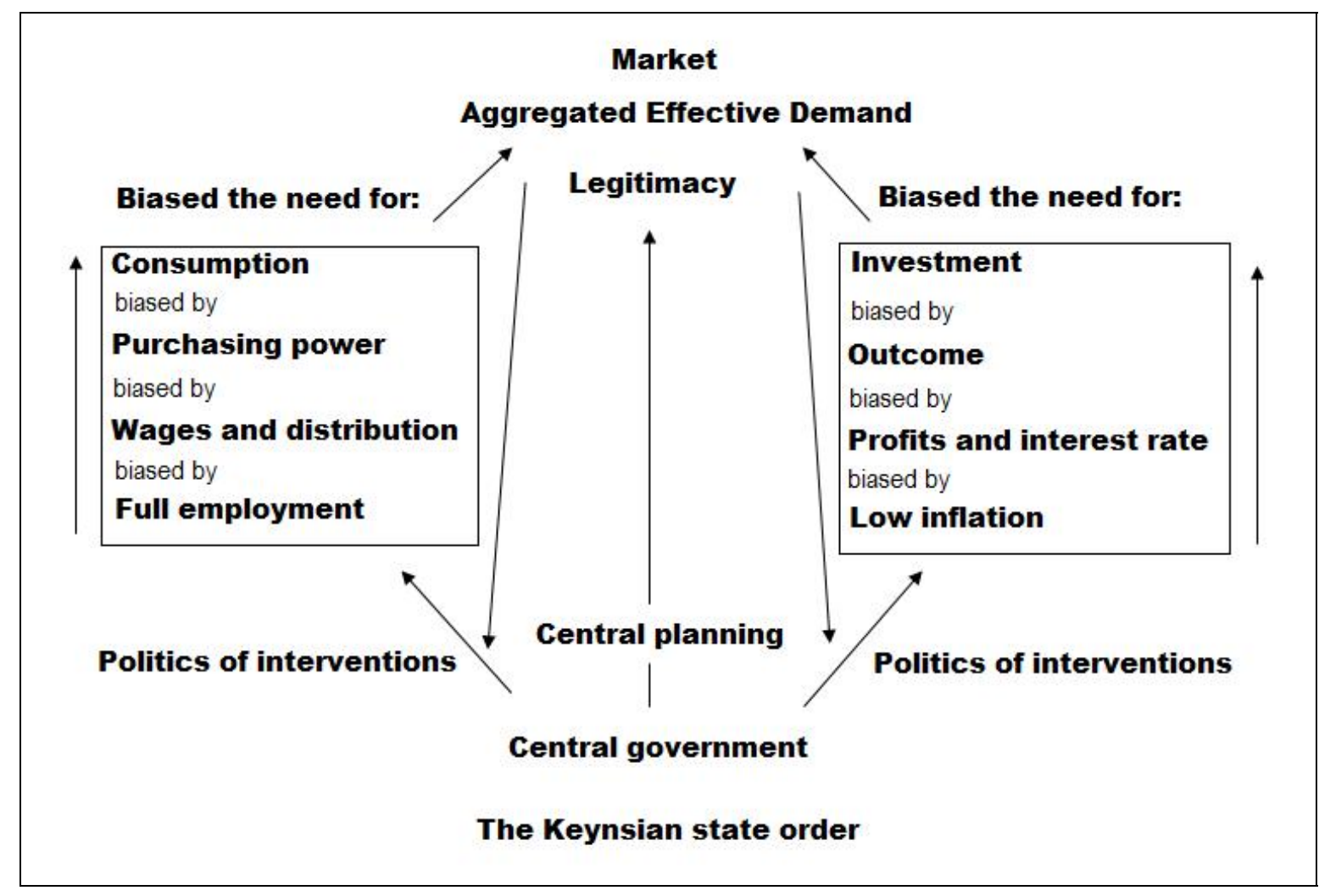

Figure 2. The structure of the Keynesian political economy

What is important here (Fig. 2) is the way Keynes provided legitimacy for the central government to initiate basic central planning, where-after to intervene and make consumption and investment adjustments according to the national Master-plan of economics and to sector plans. This meant to regulate market mechanisms for the purpose of long-term effective demand, and thereby full employment and low inflation. In return, the domain of the politics got legitimacy because of economic stability and growth success as results of the interventions. The advancement of the post war welfare state in this framework might be said to be the top point for convincing Keynesian policies with great legitimacy (Flora et al. (eds.) 1999). Optimistically, some scholars pointed out that probably a new international economic crisis would never occur again because of the balancing effect of the interventionist state (Shonfield 1969). They were wrong.

What measures empowered the interventionist state? The Keynesian approach to macro-economic crises created a new bunch of conceptual tools for economic policy and central planning by the central government. After the Second World War, these conceptual tools were widened to include sector planning, regional planning, environmental planning, and connected extensive social and regional distributive policies. The success of this type of planning and governance rested upon the assumption that the national economy was relatively closed and protected from external impacts. That situation changed during the 1980s. The markets were enlarged globally in order to let businesses get access to new markets, and the Keynesian classical principles as such failed.

As a method and a basis for knowledge Keynesianism represented a top-down rational form 
of planning, i.e. mean-ends strategies in making both growth developments and distributive policies work (Friedmann 1987, Amdam and Veggeland 1998:26-27). Politically this type of planning fitted the social democratic ideology of the time, and its insistence on market control, state ownership and monopolies and an active income and cost policy. State intervention and a planned society were considered desirable, so were also the Weberian bureaucracy as administrative executive.

Majone (1997: 139-167) has argued that the interventionist state had three main tasks: 1) macro-economic stabilisation, 2) the distribution of income and 3) the regulation of the market. The goal of macro-economic intervention was to achieve economic growth and the principle of full employment. The instruments for this were financial and monetary policy, together with active employment and industrial policy. Public monopolies dominated as executives of the infrastructure service policies.

Income distribution policy included the redistribution of resources from one social group, region and economic sector to another, as well as educational goods, supplementary benefits and health services. The goal was to level-out in-equalities for social reasons but also for the reason of secure full employment and economic growth (Einhorn and Logue 2003, Veggeland 1998).

Lastly, the interventionist policy of regulation aimed to redress 'market imperfections' such as monopolies, unfair competitive advantages, incomplete market information and incomplete access to public goods. The state distribution policy and the regulation of aggregate demand in society, is what has been called the 'social democratic welfare state', or even the 'Keynesian welfare state' (Ferrera and Rhodes (eds.) 2000). Macro-economic planning to sustain effective demand in the interventionist state was based upon complex mathematical models developed by the Norwegian economist, Ragnar Frisch, who obtained the Nobel Prize. Models used have been known under the terms "Eco-Circ", MSG and MODIS (Amdam and Veggeland 1998: 27).

The mode of governance was democratic in the sense that the Western national parliamentary government system combined the monopoly position of being Lawmaker (the Parliament) with the monopoly position (the Government) as executive of public policy, besides acting as a gatekeeper in international affairs. The state budget, the national accounts, sector policy, welfare policy, distributive policy and other areas became the object of parliamentary policy. Also public planning acts were democratic but only in the sense that political top-down "hearings" were arranged before leading to the formulation of goals for the development of regions, municipalities and sectors. Politically, this was the most popular form of state in the post-war period until the 1970-1980s. From this point in time, doubt crept into the social democratic consensus on the advantages of the interventionist state mode of governance, i.e. the national state monopoly of being an economist, politician, planning actor, producer of infra-structural and social goods and services and employer (Giddens 1998). 


\section{In the Shadow of the International Stagflation Crisis}

In the 1970s the international economy entered a crisis, the so-called "stagflation" crisis, SEE Figure 1 above, and it must be regarded as a fundamental causal factor in subsequent changes of the Keynesian state order (Veggeland 1998, 2009). Unemployment in the western industrial nations rose to $10-15 \%$ and more, besides the inflation reached dangerous levels. This represented a fundamental brake in the stable economic development formed on the basis of the Keynesian principles of state intervention. The intervention forms summarized as:

(1) Financial interventions.

(2) Direct control through laws and regulations.

(3) Institutional interventions.

(4) Sector interventions.

(5) State-run corporations.

(Østerud 1972: 30-31, Majone 1994).

The stagflation also led to a crisis in the principles of central planning and implementation acts developed under the interventionist state dominance. Actually, the crisis may be viewed as an appearance of the arising globalization and its effects arising of market changes. It hit the national institutions of the interventionist state, which occurred too narrow in the new setting, and made them fail to govern appropriately. On the one hand there was need for more cooperation and regulatory tasks across border, and on the other hand a more decentralized, competitive and task oriented public planning. It became essential to prepare a new institutional framework for cooperation of multi-actors in market defined functional networks, both in the nation-state internally and across international borders (Amin and Thrift 1995, Jessop 1994). Actually, it was the arrival of the post-national modes of international agreement-based multilevel governance that occurred, in Europe with the European Union as a predominant actor. (Hayward and Menon (eds.) 2003).

However, at the time it was difficult to imagine that the balance in economic circulation would once again reach crisis dimensions comparable with those of the interwar great Depression. Symptomatically Andrew Shonfield, the English economist, in a large work from 1969, 'Modern Capitalism', arguing from a Keynesian perspective, wrote the following:

'The central thesis of this book is that there is no reason to suppose that the patterns (crises) of the past, which have been ingeniously unraveled by historians of trade cycles, will reassert themselves in the future'. (1969:62)

But the crisis arrived in the end of the 1960s and into the 1970s. The crisis expresses itself as a stagflation crisis - stagnation and increasing unemployment combined with corresponding increase in inflation. The rate of the profit felt, in the Marxian sense, so to speak.

Using the disputed 'Phillips curve' principle ${ }^{5}$ of the empirical relation between inflation and

\footnotetext{
${ }^{5}$ Alban William Phillips, an economist, wrote a paper in 1958 titled 'The relationship between unemployment and the rate of change of money wages in the United Kingdom 1861-1957', which was published in the quarterly journal Economica. In
} 
unemployment, worked out under the Keynesian regime, as an adjusted point of departure, the phenomenon could also be illustrated by this simple diagram, Fig. 3.

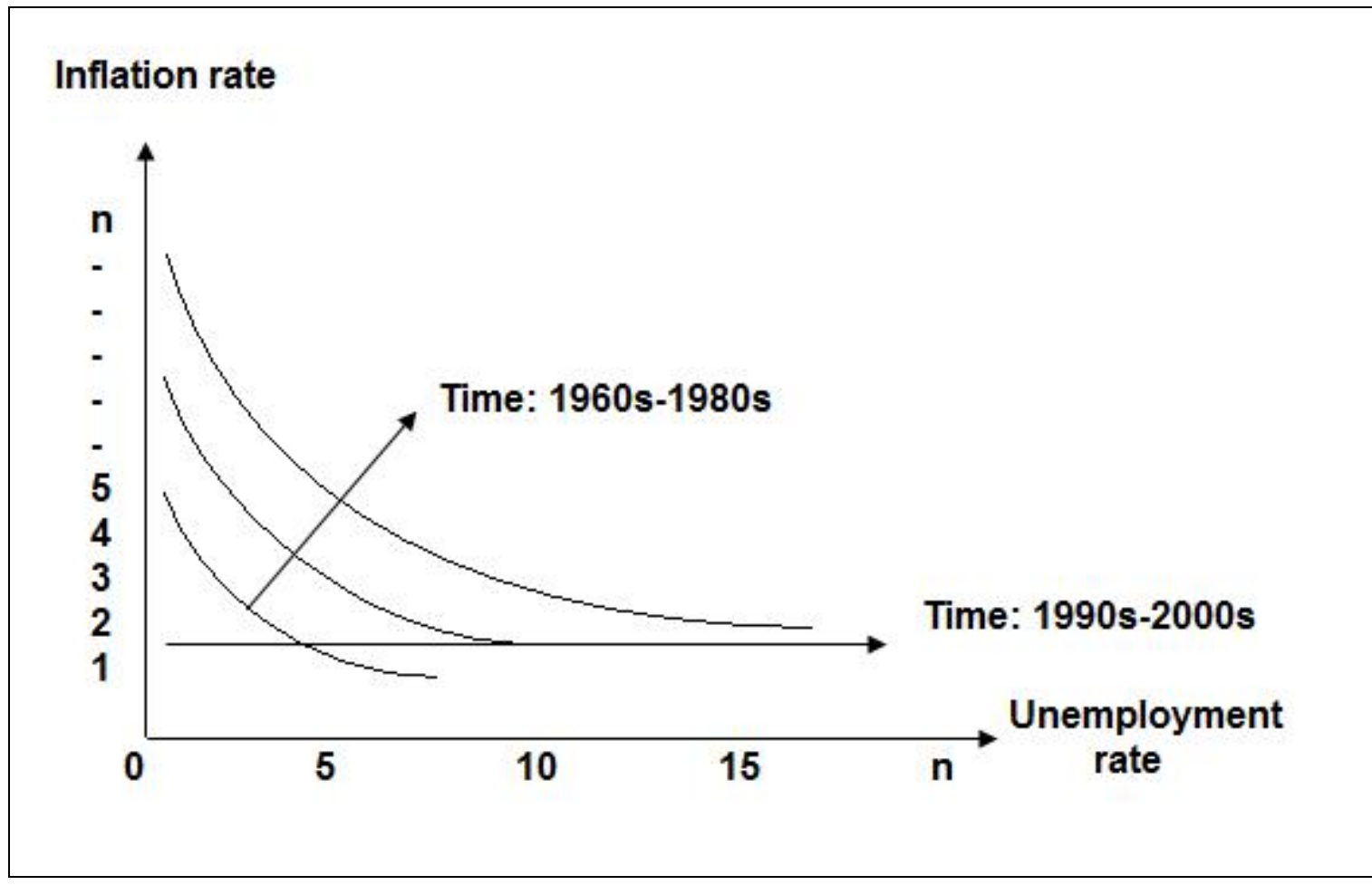

Figure 3. Curves illustrating the development of crisis tradeoffs affecting the Keynesian state: Changing stability levels for inflation - unemployment relations and growing rates of unemployment since late 1900s- 2000s.

In Fig. 3 the rate of inflation is plotted on the vertical axis, the unemployment on the horizontal axis. The arrow illustrates the passing of time. The curves view a development from a trade-cycle of balance in the 1960s with low both inflation and unemployment (the Phillip curve) - actually full employment in terms of Keynesian thinking. Then the economy got into a stage of imbalance at the end of the 1970s and 1980s, with increasing high inflation and unemployment as the normal situation. The curves view the tradeoffs between inflation and employment: Reduced effective demand in order to lessen the pressure in the economy and thereby lower the inflation makes the unemployment rate rise. The opposite around happens when the effective demand is increased, it creates an unwanted race upwards of the inflation rate (Cumes 1984).

What happened at the time was that old methods of dealing with the situation were no longer effective, or to be more correct, they did not work as expected as Fig. 3 shows. Theories and models of state interventions built upon the Keynesian General Theory were now found wanting and ineffective in most OECD member states. Measures introduced by governments to reduce rising unemployment only resulted in the level of inflation spiraling upwards. If British economy over the period examined. Similar patterns were found in other countries and in 1960. Phillips' work made explicit the empirical link between inflation and unemployment: when inflation was high, unemployment was low, and vice-versa. But empirical relations do not necessarily indicate causality, therefore a dispute work. 
demand was reduced, production fell with increasing unemployment as a result. Indications of confusion could be found amongst politicians and economists (Veggeland 1998).

Confusion was also to be found in OECD reports written under the pretence of providing advice to governments. They were unable to decide which remedies that were to be most appropriate (Mc Cracken et al.1977). A quotation (1977:14) may give a picture of the confusion, but also about strong belief in Keynesian measures, and 'avoidable errors' imprint the understanding of the crisis:

'To sum up, the immediate causes of the severe problems of 1971-75 can largely be understood in terms of conventional economic analysis. There have been underlying changes in behavior patterns and in power relationships internationally and within countries. But our reading of recent history is that the most important feature was and unusual bunching of unfortunate disturbances unlikely to be repeated on the same scale, the impact of which was compounded by some avoidable errors in economic policy. The continuing legacy of 1971-75 makes for unusual difficulties in framing policies for the years immediately ahead. We reject, however, the view that existing market-oriented economic systems and democratic political institutions have failed. What is needed is better use of existing instruments of economic policy, and better functioning and management of existing market mechanisms'. (SIC!)

Later on, in the 1980s and 1990s, OECD got out of its earlier mode of confusion. Now a certain choice between low unemployment versus low inflation was recommended, the latter should be given priority. Consequently, the unemployment rate increased to a high level in many OECD-countries, as Fig. 3 illustrates. Two things ought to be done: economic measures to keep the inflation rate low should be introduced nationally, and to be followed by comprehensive reforms and modernizing tasks in the public sector to make it more competitive (OECD 2002, 2005), and make the sector contribute more to the national income by getting into competing international markets. Great Britain and the United States grasped early the inflation-fighting strategy, and reformed deeply the economic policy - from a Keynesian inspired demand-side economic policy to a so-called supply-side economic policy of neo-liberalism (Storper and Scott (eds.) 1992). Thatcherism and Reageanism have the reforms been named, after their political leaders at the time. Other Anglo-Saxon states followed the same new strategy to get out of the crisis but with a critical rise of unemployment - normal employment rates 10-20 \% - as tradeoffs. For some OECD countries, such as Norway, had a source of income provided by oil and gas, and this provided a cushion against high unemployment. Nevertheless, stagflation was also noticeable here and in the Nordic countries in general. The economy represented a fertile ground for new thinking and transformations in the organization of economic production and the institutional function of the state and the public sector in general.

Constitutionally, the ground was prepared for the institutionalization of the regulatory state replacing partly the Keynesian interventionist (Majone 2007). The implied commitment to a global free market economy, stressed the virtues of competition and greater efficiencies through specialization and economies of scale was to be balance by acceptance of regulatory 
dirigisme replacing the old Keynesian method (Egan 2004). Economically, the new regulatory state got founded on the change away from a governmental central planned demand-side economy, to a marked-based monetary supply-side economy with the central government as the regulatory national principal. The National Central Bank services the Government as an independent arm's length body regarding implementation of interest rate and tax policies. Other arm's length bodies serve as legal surveillance agencies. It is this regulatory state that got into a grave financial and debt crisis in the 2007, and restored principles of Keynesianism and state interventionism in another context as neo-Keynesianism and neo-Interventionism, as Fig. 1 above indicates.

\section{Explanation Approaches to the Keynesian Economics in Crisis}

It has by many been said that the Keynesian policies adopted by the advanced economies in the West carried with them the seeds for their own demise, and created the basic conditions for the regulatory state formation (Cumes 1984, Friedman 1962). The Keynesian state period, 1945 - 1970s, as we have called the period, was an era of exceptionally persistent economic growth, stability, and the building of the modern welfare state; the latter of course build on the base of different social models and administrative traditions (Knill 2001, Veggeland 2007). When the international economic crisis arrived, therefore, governments applied the widely accepted and well-tried Keynesian remedies and political instruments, which they would have used in the 1950s and 1960s, and believed it to be a short-term incident (OECD 1977). But as we have viewed those remedies and instruments did not work, Fig. 3. When the governments made this experience they initially assumed that the fault lay in their domestic management and in handling international trade, and not in the validity of the Keynesian economic principles.

But as the problems continued and deepened, talk about a short-term fluctuation was heard less and less, and the crisis became more and more recognized as a long-term deep-rooted structural crisis, which claimed new remedies to overcome. People began to say that Keynesian economics had 'failed' as such. The monetarist Milton Friedman (1980) stood up and said that they had all the time been doomed to failure because of too little market and too much state. His view was that policies, which restrict production, productivity, demand and employment, have not worked, nor will it in the future.

As elaborated earlier governments applied Keynesian policies with great success as long as they effectively had the capacity and political will to move consumption and investment up or down in order to control the aggregated effective demand. However, this capacity had passed by some time in around 1970. Actually, the capacity to move the economy up remained, i.e. inflation and unemployment, but the capacity to move these factors down declined.

\section{Explanation approach 1}

The capacity to calm the economy down with rising inflation as a consequence, Fig. 3, declined because for a variety of reasons -consumption became relatively invariable. One of the main reasons was that the building of the welfare state had come to a mature level, 
meaning transfer of money to welfare services and social arrangements could not for political and economical reasons be reduced. There could be no question of abolishing allocating of money to social groups and individuals in need, when governments introduced 'deflationary' policies. Consumption and investment in the social more than economic sector became fixed. Attitudes to welfare and social security such as schools, health, social support, care for unemployed, elderly people, disables and other who could look after themselves etc. had become too deeply embedded in the polity (Arter 1999). The capacity and political will to move the economy down abolished. The inflation persisted growing. The impact on the economy of this tendency to hold up the consumption expenditure while stagnation exceeded and unemployment increased was recognized, and stimulated the cry for more market and less state - for the regulatory state.

\section{Explanation approach 2}

Gender policy also influenced the capacity of the governments. In large measure, women's liberation was made possible by the economic progress of the post-war period. The entry of females into the labor market had in our context two effects (OECD 2005). Firstly, the entry increased enormously the volume of available labor force for employment. The labor market could not offer jobs to them all. The number of people employed might increase but statistically it also contributed to the growing of unemployment, Fig. 3. Secondly, the entry of wives into the labor market meant that unemployment was less destructive of individual and family consumption levels than it had been previously. Saving or investment by family units might be reduced as economic activity turned down but a certain level of consumption persisted though. If their incomes were relatively maintained, their consumption was maintained. It influenced the bringing down of the economy through reducing the effective demand (Cumes 1984). It contributed to the failure of the Keynesian remedies.

\section{Explanation approach 3}

Related to international trade, it is a fact that a high- valued currency, leading to high import exposure, is anti-inflationary and low-valued currency increases the export exposure, which leads to greater inflation. During the post-war period free-trade exposure of goods and services dominated intergovernmental negotiations. The European Community (EC) was established, so was the European Free Trade Association (EFTA). In general, globalization of economic transactions had its start, resulting in open-up national economies.

One of the Keynesian remedies was using revaluation of national currency up or down in order to balance inflation and employment. In an open economy, and in the framework of the free-trade concept of integrated international markets, the economic and political capacity to use this instrument declined (Bratton et al. (eds.) 1996). It contributed little to help adjusting the effective demand. Therefore, in Europe it started the process of creating the Single Europe Marked (SEM) in the 1980s, and the European Monetary Union (EMU) in the 1990s, which introduced supranational surveillance and rules for trade and monetary policy (Woolcock 1996). It is this EMU which 2022 undergoes a very grave crisis. Actually, it was the regulatory state of the European Union (EU) that was founded, contextually in the wake of the Keynesian economics crisis. Goal was to 'create markets' but also to 'correct markets', 
across borders, including currency exchange, the latter limited to the EURO-zone though (Scharpf 1999).

\section{Explanation approach 4}

Lastly, there is a change of technology explanation, based upon among others the economist W. E. G. Salter. He argued (1969) that an industry may be viewed as a number of plants embodying techniques, ranging between the most modern plants embodying the current best-practice technique, and the oldest plants still in use which embodies the best-practice technique of an earlier date, and which is now outmoded. The consequences of this competition between old techniques, which generate what he terms 'extensive growth' growth which merely reproduces a given situation but fails at last - and new techniques which generate 'growth in depth', the winning situation.

He writes (Salter 1969: 65)

'The appearance of a best-practise technique has the following effects: fist, the output of the industry is expanded until price falls to equality with the total costs of plants employing the new technique; secondly, some of the older existing plants are scrapped or replaced until the operating of the oldest plant (or plants) equal the new level of price and best-practice costs. A flow of new best-practice techniques leads to a series of such equilibrium (which combine both short- and long-run elements) and so trace out the path over time of output, costs, prices and productivity'.

In the 1970s, and especially in 1980s, a new technology innovation got introduced in economic production, in manufactory industries and in service production, and in the polity in general, it was the Information and Communication Technology (ICT).

The supply-side economy viewed ICT as a new factor to boost the Keynesian economy in stagnation. In sector after sector and firm by firm, the ICT replaced the old technology and machinery. Investments went to this new sector, and the demand for highly skilled labor forces grew rapidly - and so did the wages and the consumption. Old industries lost competitive capacity and were closed down. Consequences for the Keynesian state economy have been found damaging contextually in this respect, combining impacts of new and old technology.

On one hand, the closing down of old industries contributed to massive unemployment in most of the Western countries in the actual years. On the other hand, the expansion and pressure created in the new industries based on ICT required investments, highly skilled and paid workers and specialists, which contributed to pressure and high inflation (Cumes 1984). The technological tradeoffs as explanation to the fall of the Keynesian remedies and instruments are viewed clearly by Fig. 3.

As might be expressed by the supply-side monetarists; policies which restrict the marked have never really worked. Well-managed and regulated market growth to stimulate investment, production, productivity and employment, as well as to encourage innovation and a rational use of new technology, is what is needed (Fagerberg, Mowery and Nelson (eds.) 
2005). And economy should be approached explicitly in its disaggregated, multi-sector structure, and with steady growth at the micro-economic level, is postulation stemming from Joseph A. Schumpeter. Contrary, the international credit and financial crisis of the 2010s dominates by none growth at the micro-economic and recession at the macro-economic level.

\section{The Regulatory State and Neo-Interventionism}

The emergence of the contemporary financial crisis, as already pointed out, had its beginning in the 1970s. The crisis was named a stagflation crisis. Deindustrialization and diminished economic growth in the wake of globalization processes generated unemployment as a threatening impact. The crisis was met by the national governments by radical change in their monetary policy. Among other things they started printing money to secure piece in the labor market achieved in years after the second, world war. The money was invested in work places, in upheaval of nominal salaries, and in the continued building of the welfare state. Despite such actions the parallel inflation and stagnation problems did not stop though. According to Keynesian theory and policy, as we have seen, this should be impossible, and leading economists did not know to handle the situation and forward advice to the governments.

At last the advices occurred, following an OECD recommendation path (McCracken, OECD 2002). The markets had to be enlarged globally in order to let businesses get access to new markets. It was followed up by unilateral and multilateral agreements and regulations, headed by the European Union (EU) and the World Trade Organization (WTO), to remove trade barriers; free movement of goods, capital, labor and services became the new political spoken slogan. Classical example is the strengthening of the European Commission and the introduction of the Single Marked between the years 1988-1992. It became also an important measure to market orientate and commercialize public sector services to make them contribute to the collecting national income. Organizational liberation of public institutions and agencies as arm's length bodies, dismissing political instruction authority, meant erecting independent agencies, which became embracing political mode of action. The new regulatory state was born and emerged as a form of state organization embedded in the Western democratic capitalism (Veggeland 2009, 2010). The regulatory state was guided by neoliberal ideology, and was basically involving international agreements and regulations. Those agreements and regulations were targeting opening up new markets globally to benefit capitalized industries.

The emergence of the regulatory state supported internationalization and global processes, but the unemployment rates in the Western capitalist countries remained high through the 1990s, see Fig. 3. What further happened was that the national states started raising loan abroad guaranteed by government bonds. This was done to develop the welfare state and its services further. However, the unemployment rate continued to be kept high in most Western countries. Again the high level of unemployment threatened the stability of the labor market, and the government support of the citizens was declining. Public budget deficit became considered as a practical and functional solution to the problem. Consequently, the state debt arise heavily in countries like the USA and in many EU states in the 1990s and 2000s.

The debt crisis at the time was tried solved by liberalization of the finance sector. This 
liberalization created an innovative option, namely the option for the people to borrow, from the surplus of financial capital, privatized loans. Low interest rates on privatized loans became a national measure to keep the inflation rate low and stable in accordance with monetary economic theory. The financial institutions traded loan with the only guarantee in expected rising prices in the real estate market. Streeck calls this phenomenon "privatized Keynesianism" (2012), i.e. loan based growth in private sector instead of the Keynesian principle; public loan to stabilize the effective demand in the economy. There could be , democratically spoken, no question of abolishing allocating of money through privatized loans to social groups and individuals in need, when governments introduced 'deflationary' policies. Real estate bubbles showed up and little by little they cracked; that was the situation in the USA in 2008, and it triggered the financial crisis to arise and to hit economies globally. An international double crisis was a fact, consisting of both dysfunctional public and privatized debt.

The economist, Raghuram G. Rajan, writes about the social 'Fault Lines' (2010), indicating here that the society of our time is in trouble. It is not the historical lines that is threatened to break into pieces but the society along these lines. He sees political impotence together with missing coherence in the democratic capitalism of today. Especially, he analyses the many extreme negative consequences of the catastrophically development of economic and social inequality in many Western countries, and particular in the USA.

Social justice and democratic government as guarantee for economic equality and good governance is a neglected perception. Rajan points out that for every dollar growth of income between 1976 and 2007, 58 per cent went to the one per cent of the most riches in the USA. The income of the lower and middle class people stagnated or became reduced during the same period, while the richest 10 per cent of the citizens doubled their income manifold.

This created a disorder which politically was overseen, and the policy lost legitimacy among ordinary people. Rajan put forward this dilemma in his writing, and postulates that politicians, in order to compensate for rising un-equality, liberalized the financial capital and made easier access to privatized loans for consume as a policy turn. It was an innovative way of level out economic equality seemingly by offer people cheap loans. The banks took the opportunity to make profit out of this policy by offering loan with expected rising real estate prices as guarantee, i.e. subprime loan. Large number of people bought real estate to constant rising prices which were paid by subprime loans. The belief ruled that prices would rise into the heaven. When the US Federal Bank raised the interest rate a bit many families were unable to maintain their loans, i.e. repay interest rate and part payment. This caused the effect that financial institutions broke down and became bankrupt. In the context of neo-interventionism and neo-Keynesianism some of the most important great banks were saved by the US government by supply of huge amounts of fresh money. Now it is told: The bank that exposed the federal government to the greatest potential loss during the government bailout was Citigroup, which received a grand total of $\$ 476.2$ billion in cash and guarantees, according to a new report of the Congressional Oversight Panel which oversees the TARP program.

The contemporary crisis in the USA, EU and other Western states should be named a double 
crisis, because the crisis is intimately bound to both dysfunctional public and privatized debt. Footprint of neo-interventionist policies derived from neo-Keynesian theory, see Figure 1, may be observed. On the one hand governments on both national and EU level intervenes the market economies and put money into to save banks from bankruptcy. Further supranational authorities claim reduction of public spending, which is followed by interventions to reduce private consume by forcing forward reduction of salaries together with cuts of pensions. On the other hand the European governments intervened through the EU and established a stability fund of several $€ 100$ billion administrated by the European Central Bank, aiming to be raised to reach $€ 1000$ billion in the coming years.

Indirectly but inevitably the government's new approach and attitude to state intervention became achieved as an innovative mechanism. In 2011 the European Central Bank (ECB) presented an intermediary but long term solution to heal the actual debt problems of certain states; the Long Term Re-financial Operation (LTRO). The aim of the operation was, as pointed out before, to support the banks with money by a procedure of money exchange: Banks sell expensive old bonds and gilts which are turned over in the market with $6-9$ per cent interest rate. These bonds and gilts are sold, according to the new mechanism, to the ECB with fresh money in return. The banks agree on paying the money back in three years spend of time at the same price. For the money the banks receive they pay an interest of only 1 percent. The surplus of the capital transaction the banks receive is expected to be reinvested in job creating industries.

This is how neo-interventionism and neo-Keynesianism works out today. The principles of the neo-interventionism are in Europe today mainly administrated through the international organization of the EU. EUs 'The Long Term Re-financial Operation' (LTRO) and the 'Financial Pact', is administrated by the ECB and the banks, and in contrast to the original Keynesianism principles, not by national democratic elected governments but by supranational organization; the unelected EU and its judicial agencies.

As in earlier history of political economy theories, the contemporary international economic and political crisis in the democratic capitalism will find its intermediary solution Most probably the solution will not go in the favor of liberalized financial capital which will probably come under hard regulatory international control, in Europe control means the EU. It is expected, in line with what Adam Smith and others feared that industrial monopoly interests will take over because they will be particularly able to create jobs that are needed. In addition, in Europe central EU power will grow on the cost of national democratic sovereignty.

\section{References}

Amdam, J., \& Veggeland, N. (1998). Teorier om samfunnsplanlegging [Theories of social planning]. Oslo: Universitetsforlaget.

Amin, A., \& Thrift, N. (1995). Living in the Global. In A. Amin, \& N. Thrift (Eds.), Globalization, Institutions, and Regional Development in Europe, (pp. 1-19). Oxford: Oxford University Press. 
Arter, D. (1999). Scandinavian politics today. Manchester: Manchester University Press.

Bratton, W., McCahery, J., Picciotto, S., \& Scott, C. (Eds.) (1996). International Regulatory Competition and Coordination: Perspectives on Economic Regulation in Europe and the United States. Oxford: Clarendon Press.

Cumes, J.W.C. (1984). The Reconstruction of the Global Economy. Melbourne: University Press.

Einhorn, E.S. \& Logue, J. (2003). Modern Welfare States: Scandinavian Politics and Policy in the Global Age. London: Praeger.

Egan, M. (2004). The Single Market. In M. Cini (Ed.), European Union Politics. Oxford: Oxford University Press.

Fagerberg, J., Mowery, D.C., \& Nelson, R.R. (Eds.) (2005). The Oxford Handbook of Innovation. Oxford: Oxford University Press.

Ferrera, M. \& Rhodes, M. (Eds.) (2000). Recasting European Welfare States. London: Frank Cass.

Flora, P., Kuhnle, S., \& Urwin, D. (Eds.) (1999). State formation, nation-building, and mass politics in Europe: the theory of Stein Rokkan, based on his collected works. Oxford: Oxford University Press.

Friedman, J. (1987). Planning in the Public Domain. Princeton: Princeton University Press.

Friedman, M. (1962). Capitalism and freedom. London: The University of Chicago Press.

Friedman, M. (1980). Free to choose. Harmondsworth, UK: Penguin books.

Giddens, A. (1998). The Third Way: The Renewal of Social Democracy. Cambridge: Polity Press.

Hayward, J. \& Menon, A. (Eds.) (2003). Governing Europe, Oxford: Oxford University Press.

Healey, P. (1997). Collaborative Planning: Shaping Places in Fragmented Societies. Vancouver: University of British Columbia Press.

Jessop, B. (1994). Post-Fordism and the State. In A. Amin (Ed.), Post-Fordism: A Reader, (pp. 249-279). Oxford: Blackwell. http://dx.doi.org/10.1002/9780470712726.ch8

Keynes, J. M. (1936/1964). The General Theory of Employment, Interest and Money, New York: Hardcourt, Brace \& Co.

Knill, C. (2001). The Europeanization of the National Administrations. Cambridge: Cambridge University Press. http://dx.doi.org/10.1017/CBO9780511491986

Majone, G. (1994). The Rise of the Regulatory State in Europe. West European Politics, 17(3), 77-101. http://dx.doi.org/10.1080/01402389408425031 
Majone, G. (1997). From the Positive to the Regulatory State: Causes and Consequences of Change in the Mode of Government. Journal of Public Policy, 17 (3), 139-189. http://dx.doi.org/10.1017/S0143814X00003524

McCracken, P.W. (1977). Towards full employment and price stability. Paris: OECD Publishing.

OECD (2002). Distributed Public Governance: Agencies, Authorities and other Government Bodies. Paris: OECD Publishing.

OECD (2005). Modernising Government: The way forward, Paris: OECD Publishing.

Rajan, R. G. (2010). Fault Lines: How Hidden Fractures Still Threaten the World Economy. Princeton: Princeton University Press.

Sachs, J. D. (2006, November). Welfare States, beyond Ideology. Scientific American, 20.

Salter, W. E. G. (1969). Productivity and Technical Change. Cambridge: Cambridge University Press.

Scharpf, F. (1997). Games Real Actors play: Actor-Centered Institutionalism in Policy Research. Boulder: Westview Press.

Scharpf, F. (1999). Governing in Europe: Effective and democratic? Oxford: Oxford University Press. http://dx.doi.org/10.1093/acprof:oso/9780198295457.001.0001

Schonfield, A. (1969). Modern Capitalism: The changing balance of public private power, Oxford: Oxford University Press.

Schumpeter, J. A. (1939). Business cycles: A theoretical, historical, and statistical analysis of the capitalist process. New York: McGraw-Hill.

Stewart, M. (1972), Keynes and After, Middlesex, UK: Penguin Books.

Storper, M., \& Scott, A.J. (Eds.) (1992). Pathways to Industrialization and Regional Development. London: Routledge.

Streeck, W. (2012, January). Markets now rule the world. Le Monde Diplomatique. Retrieved from http://mondediplo.com/2012/01/07crisis.

Veggeland, N. (1998). Nye rammer for offentlig planlegging. Internasjonalisering, privatisering [New frameworks for public planning: internationalization, privatization]. Oslo: Kommuneforlaget.

Veggeland, N. (2007). Paths of Public Innovation in the Global Age: Lessons from Scandinavia. Cheltenham, UK: Edward Elgar.

Veggeland, N. (2009). Taming the regulatory state: Politics and ethics. Cheltenham UK: Edward Elgar.

Veggeland, N. (2010), Den nye reguleringsstaten. Idébrytninger og styringskonflikter, [The new regulating state: conflicting ideas and conflicting management]. Oslo: Gyldendal 
Akademiske

Østerud, Ø. (1972). Samfunnsplanlegging og politisk system [Social planning and the political system], Oslo: Gyldendal.

\section{Copyright Disclaimer}

Copyright reserved by the author(s).

This article is an open-access article distributed under the terms and conditions of the Creative Commons Attribution license (http://creativecommons.org/licenses/by/3.0/). 